\title{
GAMBARAN LINGKUNGAN DAN VEKTOR DEMAM BERDARAH DENGUE DI WILAYAH KERJA PUSKESMAS TEMANGGUNG TAHUN 2017
}

\author{
Widya Hary Cahyati $^{11}$, Jauharotusf Syifa Kusrah Sanjani ${ }^{2)}$ \\ 1),2) Program StudiS1Ilmu Kesehatan Masyarakat, Universitas Negeri Semarang \\ Email: widyahary27@mail.unnes.ac.id
}

\begin{abstract}
Cases of DHF in Temanggung District had increased from 2014 - 2016 and the DHF insidence rate was in the top three of the highest level in Central Java. The aim of this research is to describe the environmental and vector of Dengue Hemorrhagic Fever in DHF Case in Temanggung Primary Health Center Working Area.This is a descriptive research with an observational analytic approach. Samples of this research are $48 \mathrm{DHF}$ cases with simple random sampling, while the mosquito samples were taken by spot surveytechniques. The instruments which used in this research are measurement and observation sheets, and questionnaire sheets. The data analysis is shown in the form of frequency table. The result showed that the average of physical environment consist of temperatures around $24.3-27.2^{\circ} \mathrm{C}, 73-94 \%$ of bumidity, and $0-67 \mathrm{~mm}$ of rainfall. The most type of water reservoirs was bathtubs, and it is located mostly in the house. The biological environment showed that there are 38 houses with the match criteria of trees, additionally there is no bush with the match criteria. The social environment showed that the category of DHF knowledge was mostly in the moderate category, the category of action respondents also showed that they mostly not supporting the prevention of DHF, and the density of occupancy was not dense. The most dominantis of mosquito was Aedes aegypti. This research's recommendation is to conduct the integrated vector control which involve all components in Temanggung Primary Health Center Working Area.
\end{abstract}

Keywords: DHF; Environment; Vector.

\begin{abstract}
ABSTRAK
Kasus DBD di Kabupaten Temanggung mengalami peningkatan dari tahun 2014 - 2016 dan IR DBD tahun 2017 termasuk peringkat ke 3 tertinggi se Jawa Tengah. Tujuan penelitian ini untuk mengetahui gambaran lingkungan dan vektor DBD pada kasus DBD di wilayah kerja Puskesmas Temanggung.Jenis penelitian ini deskripsi dengan pendekatan observasional analitik. Sampel sebesar 48 kasus DBD dengan teknik simple random sampling, sedangkan sampel nyamuk diambil dengan metode umpan orang dengan teknik spot survey. Instrumen yang digunakan adalah lembar pengukuran dan observasi, serta lembar Cara mengutip: Cahyati, W. Hary \& Sanjani, J. S. Kusrah. (2020). Gambaran Lingkungan dan Faktor Demam Berdarah Dengue di Wilayah Kerja Puskesmas Temanggung tahun 2017. Care:Jurnal Ilmiah Ilmu Kesehatan, 8(1), 12-29
\end{abstract}


kuesioner. Data yang diperoleh dianalisis secara deskriptif yang disajikan dalam bentuk tabel frekuensi. Hasil Penelitian menunjukkan bahwa lingkungan fisik diantaranya suhu 24.3-27. $2^{\circ} \mathrm{C}$, kelembaban $73-94 \%$, curah hujan $0-67 \mathrm{~mm}$, jenis tempat penampungan air paling banyak adalah bak mandi, dan letak tempat penampungan air paling banyak di dalam rumah. Pada kondisi lingkungan biologi diantaranya pada 38 rumah terdapat pepohonan yang sesuai kriteria, dan tidak terdapat semak-semak yang sesuai kriteria. Pada kondisi lingkungan sosial diantaranya pengetahuan tentang DBD paling banyak kategori sedang, tindakan responden paling banyak kategori tidak mendukung pencegahan DBD, dan kepadatan huniannya tidak padat. Nyamuk yang paling dominan ditemukan adalah Aedes aegypti. Saran dari penelitian ini untuk melakukan pengendalian vektor terpadu yang melibatkan seluruh komponen di wilayah kerja Puskesmas Temanggung.

Kata Kunci: DBD; Lingkungan; Vektor.

\section{PENDAHULUAN}

Demam Berdarah Dengue (DBD) merupakan penyakit menular yang disebabkan oleh virus denguedan ditularkan melalui nyamuk Aedes sp. Penyakit DBD masih menjadi masalah kesehatan masyarakat di dunia, karena jumlah kasus dan penyebarannya cenderung meningkat, serta sering menimbulkan Kejadian Luar Biasa (KLB). Kabupaten Temanggung merupakan salah satu daerah endemis DBD yang memiliki riwayat kasus DBD tinggi. Berdasarkan data dari Dinas Kesehatan Kabupaten Temanggung bahwa kasus DBD di Kabupaten Temanggung mengalami peningkatan dari tahun 2014 - tahun 2016. Pada tahun 2014 terdapat 405 kasus dengan Incidence Rate $(\mathrm{IR})=54,8$ dan 1 kematian dengan Case Fatality Rate $(\mathrm{CFR})=0,2 \%$, tahun 2015 terdapat 493 kasus dengan IR = 66,1 dan 3 kematian dengan $\mathrm{CFR}=0,6 \%$, tahun
2016 terdapat 821 kasus dengan $\mathrm{IR}=109$ dan 5 kematian dengan $\mathrm{CFR}=0,6 \%$, dan pada tahun 2017 terjadi penurunan yaitu terdapat 283 kasus dengan $I R=46,50$. Walaupun terjadi penurunan, IR DBD di Kabupaten Temanggung termasuk peringkat ke 3 tertinggi se Jawa Tengah.

Puskesmas Temanggung merupakan puskesmas yang paling banyak memiliki kasus DBD dibandingkan dengan puskesmas lainnya di Kabupaten Temanggung. Berdasarkan data laporan kasus DBD Puskesmas Temanggung bahwa pada tahun 2015 sebanyak 85 kasus dengan IR $=213.15$ dan 1 yang meninggal dengan $\mathrm{CFR}=1,9 \%$, pada tahun 2016 sebanyak 122 kasus dengan $I R=305.93$ dan 1 yang meninggal dengan $\mathrm{CFR}=$ 0,8\%. Akan tetapi pada tahun 2017 terjadi penurunan yaitu sebanyak 48 kasus dengan $I R=58,78$. Walaupun terjadi penurunan, Puskesmas Temanggung tetap 
menjadi puskesmas yang tertinggi kasus DBD nya dibandingkan dengan puskesmas lain di Kabupaten Temanggung.

Tingginya jumlah kasus DBD di wilayah kerja Puskesmas Temanggung didukung oleh beberapa faktor diantaranya daerah perkotaan yang padat penduduk. Penelitian Candra (2010)menyebutkan bahwa salah satu faktor risiko penularan DBD adalah pertumbuhan penduduk perkotaan yang cepat. Lingkungan pemukiman sangat besar peranannya dalam penyebaran penyakit menular, termasuk DBD. Selain dari faktor kepadatan penduduk, faktor risiko penyakit DBD lainnya yaitu adanya tempat penampungan air yang menjadi tempat perindukan nyamuk Aedes sp. Jenis tempat penampungan air yang menjadi tempat perindukan nyamuk Aedes spdibedakan menjadi tiga, yaitu (1) Tempat penampungan air untuk keperluan seharihari, seperti drum, tangki reservoir, tempayan, bak mandi atau WC, dan ember (2) Tempat penampungan air bukan untuk keperluan sehari-hari, seperti tempat minum burung, vas bunga, kulkas, dispenser, barang-barang bekas (contoh botol, plastik, ban, kaleng, dll) (3) Tempat penampungan air alamiah, seperti lubang pohon, tempurung kelapa, pelepah pisang, potongan bambu, dll (Kementerian Kesehatan RI., 2013). Berdasarkan studi pendahuluan bahwa di dalam rumah masyarakat wilayah kerja Puskesmas Temanggung banyak yang mempunyai bak mandi dan ember yang berpotensial untuk menjadi tempat perindukan nyamuk Aedes sp. Selain itu, walaupun wilayah kerja Puskesmas Temanggung termasuk daerah perkotaan, masih terdapat banyak vegetasi rindang di beberapa tempat wilayah kerja Puskesmas Temanggung, misal pepohonan dan semak-semak yang merupakan habitat nyamukAedes sp. Selain itu, adanya iklim yang tidak stabil dan curah hujan cukup banyak pada musim penghujan juga merupakan sarana perkembangbiakan nyamuk Aedes sp yang cukup potensial di wilayah kerja Puskesmas Temanggung.

Nyamuk yang berperan dalam penularan DBD di Indonesia telah diketahui yaitu Aedes aegypti dan Aedes albopictus. Seluruh wilayah Indonesia mempunyai risiko untuk DBD, karena nyamuk $A$ e. aegypti dan Ae. albopictus terdapat hampir di seluruh daerah di Indonesia. Sejauh ini vektor primer DBD di Indonesia adalah nyamuk $A$ e. aegypti, sedangkan nyamuk $A$. albopictus sebagai vektor sekunder yang telah menyebar ke seluruh pelosok daerah 
di Indonesia. Nyamuk Ae. aegypti banyak terdapat di sekitar permukiman penduduk, sedangkan nyamuk $A$ e. albopictus banyak terdapat di daerah perkebunan dan semaksemak (Ginanjar, 2008).

Di dalam setiap masalah kesehatan terutama dalam upaya pencegahan penyakit DBD, faktor perilaku manusia juga sangat berperan penting. Kecenderungan penduduk yang jarang melaksanakan kegiatan-kegiatan seperti kerja bakti untuk membersihkan lingkungan, 3M di sarana rumah dan sarana umum justru akan menguntungkan untuk perkembangbiakan nyamuk Aedes $s p$. Berdasarkan wawancara dengan Kepala Bidang P2P bahwa kegiatan PSN di masyarakat kurang optimal dikarenakan kurangnya kesadaran masyarakat akan pentingnya kegiatan PSN untuk pencegahan dini kejadian DBD.Berbagai dampak negatif dan fenomena kasus DBD yang terjadi, maka diperlukan pengendalian penyakit DBD. Pengendalian penyakit DBD dapat dilakukan dengan melakukan pengendalian vektor DBD melalui pemberantasan sarang nyamuk sesuai karakteristik lingkungan.

Upaya pengendalian DBD juga diperlukan upaya pengendalian yang dapat memutuskan mata rantai penularan penyakit yang tidak merusak lingkungan, yaitu dengan memanfaatakan bahan hayati. Upaya larvasidasi terus dikembangkan dari berbagai tumbuhan yang berpotensi sebagai larvasida. Ada beberapa tumbuhan yang berpotensi sebagai larvasida karena mengandung beberapa senyawa bioaktif, seperti saponin, flavonoid, alkaloid, tanin, dan alkenil fenol(Wulandari \& Ahyanti, 2018).

\section{METODE PENELITIAN}

Penelitian ini sudah mendapatkan persetujuan dari Komisi Etik Penelitian Kesehatan Universitas Negeri Semarang No. 088/KEPK/EC/2018. Metode penelitian dalam penelitian ini adalah deskripsi dengan pendekatan observasional analitik. Sampel penelitian ini adalah kasus DBD di wilayah kerja Puskesmas Temanggung pada tahun 2017 yang dipilih menggunakan simple random sampling, berjumlah 48 kasus DBD. Sumber data yang digunakan dalam penelitian ini ada dua, yaitu data primer (lingkungan biologi, dan lingkungan sosial pada sampel penelitian) dan data sekunder (data laporan Dinas Kesehatan Kabupaten Temanggung, Puskesmas Temanggung mengenai kasus DBD di wilayah kerja Puskesmas Temanggung, BMKG tentang data suhu udara, kelembaban, dan curah 
hujan). Instrumen dalam penelitian ini adalah lembar pengukuran dan lembar observasi serta lembar kuesioner. Teknik pengambilan data dalam penelitian ini diantaranya (1) Pengukuran, untuk mengetahui kondisi lingkungan fisik berupa suhu udara, kelembaban udara, dan curah hujan menggunakan data prakiraan cuaca $B M K G$ pada saat kejadian DBD di setiap kasus tahun 2017, (2) Observasi lapangan, untuk melakukan pendataan keberadaan tempat penampungan air, keberadaan pepohonan, keberadaan semak-semak, dan kepadatan hunian, (3) Wawancara, untuk mengetahui kondisi lingkungan sosial berupa pengetahuan tentang DBD dan tindakan pencegahan DBD, (4) Penangkapan nyamuk secara spot survey dengan metode umpan orang yang dilakukan oleh empat collector yang dilakukan pada pukul 08.00-
10.00 WIB dan pukul 16.00-18.00 WIB pada rumah kasus DBD.

\section{HASIL}

Suhu udara, kelembaban udara, dan curah hujan dapat berpengaruh kejadian DBD dan mampu mendukung perkembangbiakan nyamuk. Suhu udara, kelembaban udara, dan curah hujan pada kasus DBD wilayah kerja Puskesmas Temanggung diperoleh dari data prakiraan cuaca BMKG Jawa Tengah pada saat kejadian DBD di setiap kasus tahun 2017.Pada Tabel 1. diketahui bahwa suhu udara pada saat kejadian kasus DBD di wilayah kerja Puskesmas Temanggung tahun 2017 berkisar antara $24.3^{\circ} \mathrm{C}$ sampai $27.2^{\circ} \mathrm{C}$. Suhu udara pada kisaran tersebut merupakan suhu optimum untuk perkembangan nyamuk vektor DBD. 
Tabel 1. Hasil Pengukuran Suhu Udara, Kelembaban Udara, dan Curah Hujan

\begin{tabular}{|c|c|c|c|c|c|}
\hline No & Kasus DBD & $\begin{array}{l}\text { Tanggal } \\
\text { Sakit }\end{array}$ & $\begin{array}{c}\text { Suhu } \\
\left({ }^{\circ} \mathrm{C}\right)\end{array}$ & $\begin{array}{c}\text { Kelembaban } \\
(\%)\end{array}$ & $\begin{array}{l}\text { Curah Hujan } \\
\text { (mm) }\end{array}$ \\
\hline 1 & Responden 1 & $10-02-2017$ & 25.2 & 88.0 & Tidak Hujan \\
\hline 2 & Responden 2 & 28-01-2017 & 25.2 & 91.0 & Tidak Hujan \\
\hline 3 & Responden 3 & 07-07-2017 & 25.8 & 80.0 & $\mathrm{X}$ \\
\hline 4 & Responden 4 & 13-02-2017 & 25.3 & 91.0 & 18 \\
\hline 5 & Responden 5 & $19-03-2017$ & 25.6 & 92.0 & 34 \\
\hline 6 & Responden 6 & $17-04-2017$ & 26.2 & 88.0 & $\mathrm{X}$ \\
\hline 7 & Responden 7 & $17-02-2017$ & 25.3 & 92.0 & Tidak Hujan \\
\hline 8 & Responden 8 & $21-05-2017$ & 26.0 & 91.0 & Tidak Hujan \\
\hline 9 & Responden 9 & 05-07-2017 & 26.1 & 82.0 & $\mathrm{X}$ \\
\hline 10 & Responden 10 & 03-02-2017 & 25.2 & 92.0 & Tidak Hujan \\
\hline 11 & Responden 11 & 03-02-2017 & 26.0 & 93.0 & Tidak Hujan \\
\hline 12 & Responden 12 & 09-02-2017 & 25.5 & 83.0 & 14 \\
\hline 13 & Responden 13 & $10-02-2017$ & 25.2 & 88.0 & Tidak Hujan \\
\hline 14 & Responden 14 & 01-02-2017 & 25.5 & 92.0 & 10 \\
\hline 15 & Responden 15 & $16-03-2017$ & 26.1 & 88.0 & 41 \\
\hline 16 & Responden 16 & 06-01-2017 & 25.2 & 91.0 & Tidak Hujan \\
\hline 17 & Responden 17 & 07-03-2017 & 25.9 & 88.0 & 46 \\
\hline 18 & Responden 18 & 27-01-2017 & 25.8 & 91.0 & 14 \\
\hline 19 & Responden 19 & $25-01-2017$ & 25.0 & 95.0 & Tidak Hujan \\
\hline 20 & Responden 20 & $24-06-2017$ & 24.4 & 84.0 & Tidak Hujan \\
\hline 21 & Responden 21 & $16-02-2017$ & 24.8 & 93.0 & 20 \\
\hline 22 & Responden 22 & 02-02-2017 & 24.3 & 94.0 & 67 \\
\hline 23 & Responden 23 & 03-02-2017 & 25.2 & 92.0 & Tidak Hujan \\
\hline 24 & Responden 24 & $10-01-2017$ & 26.6 & 83.0 & Tidak Hujan \\
\hline 25 & Responden 25 & $16-02-2017$ & 24.8 & 93.0 & 20 \\
\hline 26 & Responden 26 & 01-07-2017 & 26.4 & 85.0 & $\mathrm{X}$ \\
\hline 27 & Responden 27 & $19-07-2017$ & 25.8 & 82.0 & $\mathrm{X}$ \\
\hline 28 & Responden 28 & $17-02-2017$ & 25.3 & 92.0 & Tidak Hujan \\
\hline 29 & Responden 29 & $26-02-2017$ & 25.2 & 92.0 & 59 \\
\hline 30 & Responden 30 & 01-03-2017 & 26.0 & 90.0 & 50 \\
\hline 31 & Responden 31 & $18-07-2017$ & 25.5 & 75.0 & $\mathrm{X}$ \\
\hline 32 & Responden 32 & $15-11-2017$ & 25.4 & 93.0 & 12 \\
\hline 33 & Responden 33 & $10-03-2017$ & 24.7 & 89.0 & 8 \\
\hline 34 & Responden 34 & 07-06-2017 & 26.7 & 86.0 & Tidak Hujan \\
\hline 35 & Responden 35 & 11-01-2017 & 25.7 & 87.0 & Tidak Hujan \\
\hline 36 & Responden 36 & 04-10-2017 & 27.2 & 79.0 & Tidak Hujan \\
\hline 37 & Responden 37 & $22-02-2017$ & 25.7 & 90.0 & 13 \\
\hline 38 & Responden 38 & 09-03-2017 & 25.6 & 87.0 & Tidak Hujan \\
\hline 39 & Responden 39 & 01-03-2017 & 26.0 & 90.0 & 50 \\
\hline 40 & Responden 40 & 21-03-2017 & 25.1 & 91.0 & 10 \\
\hline 41 & Responden 41 & $23-05-2017$ & 26.5 & 90.0 & Tidak Hujan \\
\hline 42 & Responden 42 & $23-05-2017$ & 26.5 & 90.0 & Tidak Hujan \\
\hline 43 & Responden 43 & 23-05-2017 & 26.5 & 90.0 & Tidak Hujan \\
\hline 44 & Responden 44 & $13-09-2017$ & 27.1 & 73.0 & Tidak Hujan \\
\hline 45 & Responden 45 & 24-01-2017 & 24.7 & 95.0 & Tidak Hujan \\
\hline 46 & Responden 46 & $27-01-2017$ & 25.8 & 91.0 & 14 \\
\hline 47 & Responden 47 & 09-07-2017 & 25.2 & 81.0 & $\mathrm{X}$ \\
\hline 48 & Responden 48 & 05-03-2017 & 26.2 & 85.0 & Tidak Hujan \\
\hline
\end{tabular}

Sumber: BMKG Jawa Tengah, 2018 
Tabel 2. Rekapitulasi Hasil Observasi Tempat Penampungan Air

\begin{tabular}{|c|c|c|c|c|c|c|c|}
\hline \multirow{2}{*}{\multicolumn{2}{|c|}{ Jenis Tempat Penampungan Air }} & \multicolumn{4}{|c|}{ Letak } & \multirow[t]{2}{*}{$\bar{\Sigma}$} & \multirow[t]{2}{*}{$\%$} \\
\hline & & Dalam & $\%$ & Luar & $\%$ & & \\
\hline Tempat & Bak mandi & 82 & 30,48 & - & 0,00 & 82 & 23,91 \\
\hline \multirow{4}{*}{$\begin{array}{l}\text { penampungan air } \\
\text { untuk keperluan } \\
\text { sehari-hari }\end{array}$} & Bak WC & 18 & 6,69 & - & 0,00 & 18 & 5,25 \\
\hline & Ember & 42 & 15,61 & 3 & 4,05 & 45 & 13,12 \\
\hline & Gentong & 2 & 0,74 & 1 & 1,35 & 3 & 0,87 \\
\hline & Drum & - & 0,00 & 1 & 1,35 & 1 & 0,29 \\
\hline \multirow{9}{*}{$\begin{array}{l}\text { Tempat } \\
\text { penampungan air } \\
\text { bukan } \\
\text { keperluan } \\
\text { hari }\end{array}$} & Barang - barang bekas & 46 & 17,10 & 22 & 29,73 & 68 & 19,82 \\
\hline & Tempat minum burung & 15 & 5,58 & 6 & 8,11 & 21 & 6,12 \\
\hline & Kolam & 3 & 1,12 & - & 0,00 & 3 & 0,87 \\
\hline & Pot tanaman & - & 0,00 & 15 & 20,27 & 15 & 4,37 \\
\hline & Vas bunga & 4 & 1,49 & - & 0,00 & 4 & 1,17 \\
\hline & Tampungan air AC & 1 & 0,37 & - & 0,00 & 1 & 0,29 \\
\hline & Dispenser & 26 & 9,67 & - & 0,00 & 26 & 7,58 \\
\hline & Akuarium & 3 & 1,12 & - & 0,00 & 3 & 0,87 \\
\hline & Penampungan kulkas & 27 & 10,04 & - & 0,00 & 27 & 7,87 \\
\hline \multirow{4}{*}{$\begin{array}{l}\text { Tempat } \\
\text { penampungan } \\
\text { alami }\end{array}$} & Lubang pohon & - & 0,00 & 1 & 1,35 & 1 & 0,29 \\
\hline & Potongan bambu & - & 0,00 & 25 & 33,78 & 25 & 7,29 \\
\hline & Cotal & 269 & 100 & 74 & 100 & 343 & 100 \\
\hline & & \multicolumn{2}{|c|}{$(78,43 \%)$} & \multicolumn{2}{|c|}{$(21,57 \%)$} & \multicolumn{2}{|c|}{$(100 \%)$} \\
\hline
\end{tabular}

Pada Tabel 2. dapat diketahui bahwa tempat penampungan air yang terletak di dalam rumah sebanyak 269 buah $(78,43 \%)$ lebih banyak dibandingkan dengan yang terletak di luar rumah yaitu sebanyak 74 buah $(21,57 \%)$.Hal ini sejalan dengan penelitian yang dilakukan oleh Sariet al.,(2012)bahwa berdasarkan letak tempat penampungan air, tempat penampungan air lebih banyak terdapat di dalam ruangan (74\%). Hal ini disebabkan karena tempat penampungan air dalam rumah, airnya sepanjang waktu digunakan untuk berbagai kebutuhan sehari-hari. Karena kondisi di dalam rumah cenderung lebih gelap, membuat udaranya cenderung lebih lembab, sehingga lebih berpotensi menjadi tempat bertelur bagi nyamuk.

Tabel 3. Rekapitulasi Hasil Observasi Keberadaan Pepohonan dan Semak-semak

\begin{tabular}{llcc}
\hline Jenis Lingkungan Biologi & Kategori & Total & $\mathbf{\%}$ \\
\hline \multirow{2}{*}{ Pepohonan } & Ada & 10 & 20,83 \\
& Tidak Ada & 38 & 79,17 \\
\hline \multirow{2}{*}{ Total } & & 48 & 100,00 \\
\hline \multirow{2}{*}{ Semak - semak } & Ada & 0 & 0,00 \\
& Tidak Ada & 48 & 100,00 \\
\hline Total & & 48 & 100,00 \\
\hline
\end{tabular}

Pada Tabel 3.dapat diketahui berdasarkan kategori ada atau tidaknya keberadaan pepohonan yang sesuai kriteria (pohon atau vegetasi rindang yang 
tingginya minimal 5 meter dan memiliki daun yang lebat dengan jarak $\leq 100 \mathrm{~m}$ dari rumah sampel) bahwa responden yang mempunyai tempat tinggal dengan kategori tidak ada pepohonan berjumlah 38 responden $(79,17 \%)$ lebih banyak dibandingkan responden yang mempunyai tempat tinggal dengan kategori ada pepohonan berjumlah 10 responden (20,83\%). Hal tersebut dikarenakan hampir semua di sekitar rumah kasus DBD hanya memiliki pepohonan yang tingginya tidak sesuai kriteria yaitu kurang dari 5 meter.

Tabel 4. Rekapitulasi Hasil Observasi Lingkungan Sosial

\begin{tabular}{|c|c|c|}
\hline Pengetahuan DBD & f & $(\%)$ \\
\hline Rendah & 0 & 0,00 \\
\hline Sedang & 27 & 56,25 \\
\hline Tinggi & 21 & 43,75 \\
\hline $\begin{array}{r}\text { Total } \\
\end{array}$ & 48 & 100,00 \\
\hline \multicolumn{3}{|c|}{ Tindakan Pencegahan DBD } \\
\hline Tidak mendukung & 29 & 60,42 \\
\hline Kurang mendukung & 18 & 37,5 \\
\hline Mendukung & 1 & 2,08 \\
\hline Total & 48 & 100,00 \\
\hline \multicolumn{3}{|l|}{ Kepadatan Hunian } \\
\hline Tidak padat ( > $10 \mathrm{~m}^{2} /$ orang) & 45 & 93,75 \\
\hline Padat $\left(\leq 10 \mathrm{~m}^{2} /\right.$ orang $)$ & 3 & 6,25 \\
\hline Total & 48 & 100,00 \\
\hline Rata-rata & $28,98 \mathrm{~m}^{2} /$ orang & \\
\hline Kepadatan paling rendah & $5,71 \mathrm{~m}^{2} /$ orang & \\
\hline Kepadatan paling tinggi & $85 \mathrm{~m}^{2} /$ orang & \\
\hline
\end{tabular}

Pada Tabel 4. menunjukkan bahwa tingkat pengetahuan responden tentang DBD paling banyak dengan kategori sedang sebanyak 27 orang $(56,25 \%)$ dan disusul dengan kategori tinggi sebanyak 21 orang $(43,75 \%)$. Kemudian tidak ada responden yang memiliki tingkat pengetahuan rendah tentang DBD $(0 \%)$.
PEMBAHASAN

Gambaran Lingkungan Fisikpada Kasus DBD

Berdasarkan Tabel 1. dapat diketahui bahwa kelembaban udara pada saat kejadian kasus DBD di wilayah kerja Puskesmas Temanggung tahun 2017 berkisar antara $73 \% \quad$ sampai 94\%.Kelembaban dapat mempengaruhi panjangnya umur nyamuk vektor DBD.Hal ini sesuai dengan penelitian Minanda (2012)yang menyatakan bahwa 
kelembaban yang ideal bagi pertumbuhan nyamuk Aedes aegypti adalah 70\% sampai 90\%.Semakin tinggi kelembaban maka akan semakin tinggi pula populasi nyamuk Aedes sp.Kelembaban terendah sebesar $71,9 \%$ sampai dengan $83,5 \%$ secara tidak langsung memberikan peluang umur (longevity) nyamuk lebih panjang untuk siklus pertumbuhan virus di dalam tubuhnya. Badan nyamuk yang kecil memiliki permukaan yang besar oleh karena sistem pernafasan dengan trakea. Padawaktu terbang nyamuk memerlukan oksigen lebih banyak, sehingga trakea terbuka. Keadaan ini menyebabkan penguapan air dan tubuh nyamuk menjadi lebih besar. Kelembaban udara optimal akan menyebabkan daya tahan hidup nyamuk bertambah (Sucipto\&Raharjo, 2015).

Hal ini sesuai dengan penelitian Lutfianaet al.,(2012) yang mengatakan bahwa Kota Semarang mempunyai tingkat risiko penyakit DBD yang tinggi sehingga termasuk daerah endemis penyakit DBD karena terletak pada ketinggian 0,75 meter - 348 meter di atas permukaan laut dengan suhu udara berkisar $25^{\circ} \mathrm{C}$ sampai $30^{\circ} \mathrm{C}$ dan kelembaban udara berada di antara 62\% sampai $84 \%$.Nyamuk dapat bertahan hidup pada suhu rendah, tetapi metabolismenya menurun atau bahkan terhenti bila suhunya turun sampai di bawah suhu kritis. Pada suhu yang lebih tinggi dari $35{ }^{\circ} \mathrm{C}$ juga mengalami perubahan dalam arti lebih melambatnya proses-proses fisiologis. Rata-rata suhu optimum untuk pertumbuhan nyamuk adalah $25^{\circ} \mathrm{C}$ sampai $27^{\circ} \mathrm{C}$ (Hikmawati, 2012).

Berdasarkan Tabel 1. dapat diketahui bahwacurah hujan pada saat kejadian kasus DBD di wilayah kerja Puskesmas Temanggung tahun 2017 berkisar antara 0mm sampai 67mm.Curah hujan yang meningkat menyebabkan tempat perindukan nyamuk vektor DBD juga meningkat.Hal ini sesuai dengan penelitian yang dilakukan oleh Zubaidah (2012)di Kota Banjar Jawa Barat yang merupakan daerah rawan DBD bahwa setelah dilakukan interpolasi terhadap data curah hujan Kota Banjar tahun 2012 didapatkan Indeks Curah Hujan Kecamatan Banjar rata-rata $48 \mathrm{~mm} / \mathrm{hr}$ sampai $49 \mathrm{~mm} / \mathrm{hr}$. Hal tersebut merupakan warning yang dapat memberikan sinyal akan terjadinya peningkatan kasus penyakit DBD.

Tempat penampungan air merupakan tempat perindukan vektor DBD.Terdapat tiga jenis tempat penampungan air yang 
merupakan tempat perindukan vektor DBD, yaitu tempat penampungan air untuk keperluan sehari-hari, tempat penampungan air bukan untuk keperluan sehari-hari, dan tempat penampungan air alamiah. Berdasarkan letaknya, terdapat dua letak, yaitu di dalam rumah dan di luar rumah.Berdasarkan Tabel 2. dapat diketahui bahwa jenis tempat penampungan air yang paling banyak ditemukan pada rumah kasus DBD wilayah kerja Puskesmas Temanggung adalah bak mandi sebanyak 82 buah (23,91\%), barang-barang bekas sebanyak 68 buah (19,82\%), dan ember sebanyak 45 buah $(13,12 \%)$.Jenis tempat penampungan air yang ditemukan pada penelitian ini kebanyakan adalah berupa bak mandi. Hal ini sejalan dengan penelitian yang dilakukan oleh Setyobudi (2011)yang menyatakan bahwa keberadaan breeding place paling banyak terinfeksi jentik di Kelurahan Sananwetan Kecamatan Sananwetan Kota Blitar adalah bak mandi. Hal ini dikarenakan bak mandi dimiliki oleh hampir seluruh masyarakat. Bak mandi merupakan tempat yang disukai nyamuk karena dibiarkan terbuka dan banyak menampung air sehingga menarik perhatian nyamuk untuk berkembang biak. Nyamuk merasa aman dan nyaman untuk meletakkan telurnya di tempat tersebut.
Berdasarkan pengelompokan macammacam tempat penampungan air bahwa yang paling banyak ditemukan pada rumah kasus DBD wilayah kerja Puskesmas Temanggung adalah tempat penampungan air bukan untuk kehidupan sehari-hari yaitu sebanyak 168 buah dan yang paling sedikit adalah tempat penampungan air alami yaitu sebanyak 26 buah. Hal tersebut dikarenakan tempat penampungan air tersebut digunakan untuk keperluan penampungan air bagi kebutuhan rumah tangga dan jenis-jenis tempat penampungan airnya juga bervariasi.

\section{Gambaran Lingkungan Biologipada Kasus DBD}

Lingkungan biologi pada kasus DBD wilayah kerja Puskesmas Temanggung ditunjukkan oleh keberadaan pepohonan dan semak-semak.Pepohonan rindang merupakan tempat nyamuk vektor DBD akan beristirahat karena memiliki kelembaban tinggi dan karena tidak terkena cahaya matahari, sedangkan semak-semak merupakan tumbuhan berumpun dengan ketinggian maksimal 2 meter dan luasan $\geq 2 \mathrm{~m}^{2}$ sebagai tempat peristirahatan nyamuk vektor DBD.

Keberadaan pepohonan ataupun tanaman tetap memiliki risiko tempat nyamuk vektor DBD. Hal ini berbeda dengan 
penelitian yang dilakukan oleh Anwaret al.,(2014)bahwa jumlah nyamuk terbanyak yang didapatkan di wilayah Gandus, yaitu sebanyak 18 ekor. Keadaan di sekitar lokasi dikelilingi pepohonan menyerupai hutan, terdapat beberapa genangan air besar berupa rawa-rawa, kolam, dan genangan sisa hujan.Hal tersebut membuktikan bahwa keberadaan pepohonan yang rindang dapat mempengaruhi perkembangbiakan vektor DBD. Hal ini berkaitan dengan ekologi dan biologi nyamuk yaitu suhu, kelembaban, dan cahaya berperan dalam mendukung perkembangbiakan nyamuk vektor DBD.

Pada Tabel 3. dapat diketahui berdasarkan kategori ada atau tidaknya keberadaan semak-semak yang sesuai kriteria (tumbuhan berumpun dengan ketinggian maksimal 2 meter dan luasan $\geq 2 \mathrm{~m}^{2}$ dengan jarak $\leq 100 \mathrm{~m}$ dari rumah sampel) bahwa semua responden mempunyai tempat tinggal yang masuk dalam kategori tidak ada semak-semak (100\%). Hal tersebut dikarenakan hampir semua rumah kasus DBD wilayah kerja Puskesmas Temanggung berada di lingkungan yang padat rumah bahkan beberapa di dalam perumahan sehingga tidak ada semaksemak yang berada di sekitar rumah kasus
DBD wilayah kerja Puskesmas Temanggung. Hal ini kurang sesuai dengan penelitian yang dilakukan oleh Rosa (2009) bahwa dalam hasil penangkapan nyamuk vektor DBD yaitu Ae. albopictus terdapat di area lokasi semak belukar dan perkebunan. Pada penelitian Cahyati (2006) mengatakan bahwa setelah menggigit (menghisap darah) dan selama menunggu pematangan telur nyamuk $A e$. aegypti beristirahat di tempat-tempat gelap, lembab, dan sedikit angin, misalnya rerumputan, tanah lembab, dan semaksemak.

\section{Gambaran Lingkungan Sosialpada}

\section{Kasus DBD}

Lingkungan sosial pada kasus DBD wilayah kerja Puskesmas Temanggung ditunjukkan oleh pengetahuan DBD, tindakan pencegahan DBD, dan kepadatan hunian. Pengetahuan DBD meliputi pengetahuan masyarakat wilayah kerja Puskesmas Temanggung tentang definisi DBD, penyebab DBD, cara penularan DBD, tempat perindukan nyamuk, dan pencegahan DBD. Tindakan pencegahan DBD meliputi tindakan masyarakat wilayah kerja Puskesmas Temanggung yang mendukung atau tidaknya dengan pencegahan DBD terkait tindakan $3 \mathrm{M}$ plus dan tindakan abatisasi. 
Sedangkan kepadatan hunian meliputi kepadatan hunian dalam satu rumah di rumah sampel dengan cara menghitung perbandingan antara luas ruangan dalam rumah dengan jumlah penghuni rumah.Standar WHO memiliki standar rumah layak dengan luas $10 \mathrm{~m}^{2} /$ orang, jika kepadatan huniannya $\geq 10 \mathrm{~m}^{2} /$ orang menujukkan bahwa kepadatan hunian memenuhi syarat atau tidak padat, namun jika kepadatan huniannya $\leq 10 \mathrm{~m}^{2} /$ orang menujukkan bahwa kepadatan hunian tidak memenuhi syarat atau padat. Semakin padat penghuni dalam satu rumah, semakin tinggi kasus penularan DBD.

Hal ini sejalan dengan penelitian yang dilakukan oleh Yusnita (2008)di Desa Balung Lor Kecamatan Balung Kabupaten Jember bahwa tingkat pengetahuan responden antara yang sedang dengan yang tinggi hampir seimbang yaitu sebanyak 51,51\% dan 48,49\%. Responden yang berpengetahuan tinggi mempunyai peluang untuk berperilaku baik dalam pencegahan DBD dibandingkan dengan responden yang berpengetahuan rendah, karena pengetahuan berpengaruh dengan motivasi awal bagi seseorang dalam berperilaku. Pengetahuan masyarakat tentang DBD dan pencegahannya akan mendorong masyarakat untuk melakukan tindakan dalam pencegahan DBD.

Penelitian yang dilakukan oleh Yulianto (2013) menyatakan bahwa pengetahuan yang tidak baik berisiko 10,7 kali untuk terkena DBD dibandingkan dengan pengetahuan yang baik. Pengetahuan seseorang dipengaruhi oleh pendidikan. Pendidikan masyarakat di Kepulauan Meranti mayoritas adalah SMA (63,5\%). Hal ini disebabkan kurangnya penyuluhan tentang DBD yang dilakukan oleh pihak puskesmas. Semakin tinggi pendidikan seseorang, maka wawasan yang dimilikinya akan semakin luas sehingga pengetahuan pun juga akan meningkat, sebaliknya rendahnya pendidikan akan mempersempit wawasannya sehingga akan menurunkan tingkat pengetahuan terhadap masalah kesehatan.

Dari Tabel 4. menunjukkan bahwa tindakan responden tentang pencegahan DBD paling banyak dengan kategori tidak mendukung pencegahan DBD yaitu sebanyak 29 orang $(60,42 \%)$ dan disusul dengan kategori kurang mendukung pencegahan DBD yaitu sebanyak 18 orang $(37,5 \%)$. Kemudian tindakan yang mendukung pencegahan DBD hanya terdapat 1 orang $(2,08 \%)$. Hal ini sejalan dengan penelitian yang dilakukan oleh 
Santhiet al.,(2014) bahwa pada melaksanakan 3M (menguras, menutup, penelitiannya menunjukkan tindakan baik dan mengubur), abatisasi, dll. sebanyak 43 orang $(48,9 \%)$ dan tidak baik sebanyak 45 orang $(51,2 \%)$. Penelitian yang dilakukan oleh Simson (2017)menunjukkan bahwa responden yang bersikap positif terhadap tindakan pencegahan DBD sebanyak 163 responden $(47,9 \%)$ dan yang bersikap negatif terhadap tindakan pencegahan DBD sebanyak 177 responden (52,1\%).

Dalam penelitian Ipaet al.,(2009) menunjukkan bahwa meskipun tingkat pengetahuan sudah baik namun tidak diikuti dengan tindakan dalam pencegahan dan pengendalian DBD, tidak memberikan dampak yang signifikan terhadap jumlah kasus. Menurut Teori L Green, perilaku ditentukan oleh 3 faktor utama yaitu predisposing (yang mempermudah terjadinya perilaku), faktor pemungkin (pendukung perilaku), dan faktor penguat (tokoh masyarakat, peraturan UU, dsb). Jadi meskipun pengetahuan masyarakat terhadap penanggulangan DBD sudah baik, tapi belum cukup untuk mengurangi jumlah kasus. Hal ini karena pengetahuan bisa bermakna terhadap penurunan kasus apabila dibersamai dengan pelaksanaan pemberantasan, misalnya dengan

Dari Tabel 4. menujukkan bahwa kepadatan hunian pada kasus DBD wilayah kerja Puskesmas Temanggung lebih banyak pada kategori tidak padat yaitu sebanyak 45 rumah $(93,75 \%)$ dibandingkan dengan kategori padat yaitu sebanyak 3 rumah (6,25\%). Pada Tabel 4. juga dapat disimpulkan bahwa kepadatan hunian kasus DBD wilayah kerja Puskesmas Temanggung paling tinggi adalah $85 \mathrm{~m}^{2}$ /orang dan kepadatan hunian paling rendah $5,71 \mathrm{~m}^{2} /$ orang dengan rata-rata $28,98 \mathrm{~m}^{2}$ /orang. Hal ini sejalan dengan penelitian yang dilakukan oleh Djatiet al.,(2010)bahwa di dalam penelitiannya juga terdapat kepadatan hunian rumah yang tidak padat $(98,6 \%)$. Hal ini disebabkan kepadatan hunian bukan merupakan faktor kausatif terjadinya DBD, tetapi dapat menjadi faktor risiko apabila bersama dengan faktor risiko lainnya seperti mobilitas, sanitasi lingkungan, kepadatan vektor, dan tindakan terhadap DBD.

Jumlah penghuni rumah yang mempengaruhi kepadatan hunian secara tidak langsung juga mempengaruhi keberadaan jentik Aedes sp pada rumah 
karena semakin banyak anggota keluarga maka semakin banyak aktifitas yang dilakukan oleh anggota keluarga yang berpotensi menjadi tempat perkembangbiakan vektor DBD. Dari hasil penelitian oleh Laguet al.,(2017)dapat diketahui bahwa jentik Aedes sp lebih banyak ditemukan pada rumah yang jumlah penghuninya banyak dan termasuk dalam kategori keluarga besar. Hal ini disebabkan rumah yang diperiksa dan jumlah penghuninya banyak dan termasuk dalam kategori keluarga besar memiliki lebih banyak tempat penampungan air dibanding rumah yang jumlah penghuninya sedikit dan termasuk dalam kategori keluarga kecil sehingga peluang bagi jentik untuk berkembangbiak lebih banyak.Kepadatan hunian pada kasus DBD wilayah kerja Puskesmas Temanggung berbeda dengan teori dikarenakan sebagian besar penghuni pada rumah kasus DBD bekerja atau melanjutkan pendidikannya di luar Kabupaten Temanggung, sehingga lebih lama bertempat tinggal di luar Kabupaten Temanggung daripada di rumah asli yang berada di Kabupaten Temanggung dan tidak dihitung dalam kepadatan hunian.

\section{Gambaran Vektorpada Kasus DBD}

Penentuan vektor DBD dapat didasarkan pada dominansi jenis nyamuk. Pada hasil penelitian ini diketahui bahwa bahwa jenis nyamuk yang paling banyak tertangkap di rumah kasus DBD wilayah kerja Puskesmas Temanggung yaitu $A e$. aegypti yaitu sejumlah 13 nyamuk (52\%). Sementara jenis nyamuk yang tertangkap selain Aedes sp adalah Culex vishnui yaitu sebanyak 12 nyamuk (48\%). Hasil tersebut sejalan dengan Hadiet al., 2012)yang menyebutkan bahwa jenis nyamuk yang tertangkap paling banyak ditemukan adalah Ae. aegypti pada daerah endemis DBD. Hal ini sesuai juga dengan penelitian yang dilakukan oleh Trovanciaet al., 2016)bahwa penelitian yang telah dilakukan pada bulan Oktober hingga bulan Desember 2016 mengenai deteksi transmisi horizontal virus dengue pada nyamuk wild Ae. aegypti di Kota Manado didapatkan dari seluruh nyamuk yang ditangkap 65 nyamuk wild Ae. aegypti, 6 nyamuk Ae. albopictus, dan 3 nyamuk culex spp. Dari 65 nyamuk wild Ae. aegypti 41 nyamuk betina.

Jenis nyamuk $A$ e. aegypti di daerah wilayah kerja Puskesmas Temanggung menyebabkan potensi host terkena gigitan Ae. aegypti semakin tinggi. Tingginya potensi gigitan nyamuk oleh $A$ e. aegypti pada manusia mengakibatkan potensi perpindahan agen DBD dari manusianyamuk-manusia juga semakin meningkat, 
sehingga rantai penularan DBD dapat terjadi.

Berdasarkan lokasi penangkapan, distribusi vektor DBD terdapat 2 lokasi yaitu di dalam rumah dan di luar rumah. Berdasarkan hasil penelitian, diketahui bahwa jumlah vektor DBD yang paling banyak tertangkap yaitu pada lokasi dalam rumah dengan jenis spesies terbanyak yaitu Ae. Aegyptiyaitu sejumlah 13 nyamuk $(56,52 \%)$. Hasil tersebut sesuai dengan penelitian yang dilakukan oleh Azizah\& Betty(2010)bahwa responden yang positif terkena DBD dan terbiasa tinggal di dalam rumah pada pagi hari sebanyak 24 orang $(82,8 \%)$ lebih besar dibandingkan dengan yang tidak terbiasa tinggal di dalam rumah pada pagi hari sebanyak 5 orang $(17,2 \%)$.

Pada penelitian oleh Fadillaet al.,(2015) mengatakan bahwa nyamuk $A$ e. aegypti menghisap darah lebih banyak di dalam rumah pada jam 10.00-11.00 dan 16.0017.00. Kondisi tersebut dikarenakan nyamuk vektor DBD bersifat antropofilik dan endofagik. Pada hasil penelitiannya nyamuk $A$ e. aegypti dilaporkan dominan di daerah perkotaan dan hidup di dalam rumah. Selain itu, tempat penampungan air seperti bak mandi, ember, dispenser, dll merupakan wadah yang mendukung perkembangbiakan nyamuk terutama $A e$. aegypti. Wadah perkembangbiakan nyamuk tersebut yang mendominasi di daerah wilayah kerja Puskesmas Temanggung.

Secara teoritis, aktivitas menghisap darah vektor DBDdiketahui terjadi hampir sepanjang hari sejak pagi sampai sore dengan puncak waktu pukul 08.00-10.00 WIB dan 15.00-18.00 WIB. Berdasarkan hasil penelitian, diketahui bahwa aktivitas menggigit nyamuk paling tinggi terdapat pada pukul 16.00 - 17.00 WIB dengan jenis spesies nyamuk terbanyak adalah $A$ e. aegypti sebanyak 7 nyamuk. Hal tersebut sesuai dengan penelitian yang dilakukan oleh Ridha et al., (2017)yang mengatakan bahwa perilaku menghisap darah nyamuk Aedes sp betina terjadi setiap dua sampai tiga hari sekali pada pagi hari sampai sore hari yakni pada pukul 08.00-12.00 dan pukul 15.00-17.00. Hal ini sejalan juga dengan penelitian yang dilakukan oleh Syahribulanet al., 2012) bahwa jumlah nyamuk Ae. aegypti yang menghisap darah baik dengan metode umpan orang dalam maupun dengan metode umpan orang luar menunjukkan kesamaan waktu aktvitas menghisap darah tertinggi yaitu pada pukul 17.00-18.00 WITA (atau 16.0017.00 WIB). Hal ini disebabkan karena pada saat penduduk di kelurahan tersebut 
khususnya penghuni rumah telah berkumpul kembali setelah melakukan aktivitas.

\section{KESIMPULAN}

Kondisi lingkungan fisik seperti suhu udara, kelembaban udara, dan curah hujan pada kasus DBD wilayah kerja Puskesmas Temanggung berisiko rentan pertumbuhan nyamuk dikarenakan berkondisi iklim sedang/tropis yang sesuai dengan perkembangbiakan. Terdapat banyak tempat penampungan air yang sesuai dengan tempat perindukan nyamuk vektor DBD. Keberadaan pepohonan pada sekitar rumah kasus DBD wilayah kerja Puskesmas Temanggung jumlahnya sedikit (sebagian besar hanya memiliki satu pohon dan tingginya kurang dari 5 meter) dan juga tidak ada keberadaan semaksemak yang tumbuh di sekitar rumah kasus DBD wilayah kerja Puskesmas Temanggung. Kondisi lingkungan sosial yaitu sebagian besar responden memiliki pengetahuan yang sedang dan tinggi, akan tetapi tindakan pencegahan DBD sangat minim. Kepadatan hunian pada rumah kasus DBD sebagian besar tidak padat. Jenis nyamuk yang tertangkap dan berpotensi sebagai vektor DBD yaitu $A$. agypti yang lebih banyak ditemukan di sekitar tempat penampungan air dalam rumah pada sore hari.

\section{SARAN}

Disarankan bagi peneliti berikutnya agar dapat melakukan penelitian lebih lanjut mengenai tingkat sebaran vektor dan mobilitas masyarakat dengan kejadian DBD di wilayah kerja Puskesmas Temanggung.

\section{REFERENSI}

Anwar, C., Lavita, R.A., \& Handayani, D. (2014). Identifikasi dan Distribusi Nyamuk Aedes sp. Sebagai Vektor Penyakit Demam Berdarah Dengue di Beberapa Daerah di Sumatera Selatan. $M K S, 46(2), 111-117$.

Azizah, G., Betty, R. . (2010). Analisis Faktor Risiko Kejadian Demam Berdarah Dengue di Desa Mojosongo Kabupaten Boyolali. Eksplanasi, 5(2), 1-9.

Cahyati, W.H., S. (2006). Dinamika Aedes aegypti sebagai Vektor Penyakit. Jurnal Kemas, 2(1), 38-48.

Candra, A. (2010). Demam Berdarah Dengue: Epidemiologi, Patogenesis, dan Faktor Risiko Penularan. Aspirator, 2(2), 110-119.

Djati, A.P., Rahayujati, B., \& Raharto, S. (2010). Faktor Risiko Demam Berdarah Dengue di Kecamatan Wonosari Kabupaten Gunung Kidul Provinsi DIY Tahun 2010. Prosiding Seminar Nasional Kesehatan, 1-16.

Fadilla, Z., Hadi, U.K., \& Setiyaningsih, S. (2015). Bioekologi Vektor Demam Berdarah Dengue (DBD) serta Deteksi Virus Dengue pada Aedes aegypti (Linnaeus) dan Ae. albopictus (Skuse) (Diptera: Culicidae) di Kelurahan endemik DBD Bantarjati, Kota Bogor. Jurnal Entomologi Indonesia, 12(1), 31-38.

Ginanjar, G. (2008). Apa yang Dokter Anda Tidak Katakan tentang Demam Berdarah. PT. Bentang Pustaka. 
Hadi, U.K., Soviana, S., \& Gunandini, D.D. (2012). Aktivitas Nokturnal Vektor Demam Berdarah Dengue di Beberapa Daerah di Indonesia. Jurnal Entomologi Indonesia, 9(1), 1-6.

Hikmawati I. (2012). Analisis Surveilens Vektor, Lingkungan Fisik, dan Perilaku pada Epidemi Demam Berdarah Dengue (DBD) di Desa Bojongsari Kecamatan Kembaran. Jurnal Ilmiah Ilmu-Ilmu Kedokteran, 15(3), 18-24.

Ipa, M., Lasut, D., Yuliiasih, Y., \& Delia, T. (2009). Gambaran Pengetahuan, Sikap, dan Tindakan Masyarakat serta Hubungannya dengan Kejadian Demam Berdarah Dengue di Kecamatan Pangandaran Kabupaten Ciamis. Aspirator, 1(1), 16-21.

Kementerian Kesehatan RI. (2013). Buku Saku Pengendalian Demam Berdarah Dengue untuk Pengelola Program DBD Puskesmas. Direktorat Jendral Pengendalian Penyakit dan Penyehatan Lingkungan Kementrian Kesehatan Republik Indonesia.

Lagu, A.M., Damayati, D.S., \& Wardiman, M. (2017). Hubungan Jumlah Penghuni, Jumlah Tempat Penampungan Air dan Pelaksanaan 3M Plus dengan Keberadaan Jentik Nyamuk Aedes sp di Kelurahan Balleangin Kecamatan Balocci Kabupaten Pangkep. Higiene, 3(1), 22-29.

Lutfiana, M., Winarni, T., Zulmiati., \& Novarizqi, L. (2012). Survei Jentik Sebagai Deteksi Dini Penyebaran Demam Berdarah Dengue (DBD) Berbasis Masyarakat dan Berkelanjutan. Jurnal Ilmiah Mahasiswa, 2(1), 56-63.

Minanda, R. K. (2012). Studi Kasus Hubungan Kondisi Iklim dengan Kejadian DBD di Kota Semarang Tahun 2002 2011. Jurnal Kesehatan Masyarakat, 1(2), 1039-1046.

Ridha, M. R., Fadilly, A., \& Rosvita, N. A.
(2017). Aktivitas nokturnal Aedes (stegomyia) aegypti dan Aedes (stegomyia) albopictus di berbagai daerah di Kalimantan. Journal of Health Epidemiology and Communicable Diseases, 3(2), 50-55. https://doi.org/10.22435/jhecds.v3i 2.1715

Rosa, E. (2009). Jenis - Jenis Nyamuk yang Tertangkap di Pekon Way Mengaku Kecamatan Balik Bukit Kabupaten Lampung Barat. J.Sains MIPA, 15(2), 135-140.

Santhi, N.M.M., Darmadi, I G.W., \& Aryasih, I. (2014). Pengaruh Pengetahuan dan Sikap Masyarakat tentang DBD terhadap Aktivitas Pemberantasan Sarang Nyamuk di Desa Dalung Kecamatan Kuta Utara Tahun 2012. Jurnal Kesehatan Lingkungan, 4(2), 152-155.

Sari, P., Martini., \& Ginanjar, P. (2012). Hubungan Kepadatan Jentik Aedes sp dan Praktik PSN dengan Kejadian DBD di Sekolah Tingkat Dasar di Kota Semarang. Jurnal Kesehatan Masyarakat, 1(2), 413-422.

Setyobudi, A. (2011). Faktor - Faktor yang Berhubungan dengan Keberadaan Jentik Nyamuk di Daerah Endemik DBD di Kelurahan Sananwetan Kecamatan Sananwetan Kota Blitar. Peran Kesehatan Masyarakat Dalam Pencapaian MDG's Di Indonesia, 273-281.

Simson. (2017). Perilaku Ibu Rumah Tangga dengan Kejadian Demam Berdarah Dengue. Wawasan Kesehatan, 3(2), 40-50.

Sucipto, P.T., Raharjo, M., \& N. (2015). Faktor - Faktor yang Mempengaruhi Kejadian Penyakit Demam Berdarah Dengue (DBD) dan Jenis Serotipe Virus Dengue di Kabupaten Semarang. Jurnal Kesehatan Lingkungan Indonesia, 14(2), 51-56.

Syahribulan., Biu, F.M., \& Hassan, M.S. (2012). Waktu Aktivitas Menghisap 
Darah Nyamuk Aedes aegypti dan Aedes albopictus di Desa Pa'lanassang Kelurahan Barombong Makassar Sulawesi Selatan. Jurnal Ekologi Kesehatan, 11(4), 306-314.

Trovancia, G., Sorisi, A., \& Tuda, J. (2016). Deteksi Transmisi Virus Dengue pada Nyamuk Wild Aedes aegypti Betina di Kota Manado. Jumal E-Biomedik, 4(2), 1-5.

Wulandari, K., \& Ahyanti, M. (2018). Efektivitas Ekstrak Biji Bintaro (Cerbera manghas) sebagai Larvasida Hayati pada Larva Aedes aegypti Instar III. Jurnal Kesehatan, 9(2), 218224.

Yulianto, B., \& F. (2013). Faktor - Faktor yang Berhubungan dengan Kejadian Demam Berdarah Dengue (DBD) di Puskesmas Selatpanjang Kabupaten Kepulauan Meranti. Jurnal Kesehatan Komunitas, 2(3), 113-116.

Yusnita, E. (2008). Faktor-faktor Perilaku yang Berbubungan dengan Kejadian Demam Berdarab Dengue (DBD) di Desa Balung Lor Kecamatan Balung Kabupaten Jember. Universitas Jember.

Zubaidah, T. (2012). Dampak Perubahan Iklim terhadap Kejadian Penyakit Demam Berdarah Dengue di Kota Banjarbaru, Kalimantan Selatan Selama Tahun 2005-2010. Jurnal Epidemiologi Dan Penyakit Bersumber Binatang, 4(2), 59-65. 